\title{
Indoor radon concentration levels, gamma dose rates and impact of geology - A case study in Kotli, State of Azad Jammu and Kashmir, sub-Himalayas, in Pakistan
}

\author{
A. IQBAL ${ }^{1}$, M. SHAHID BAIG ${ }^{2}$, M. AKRAM ${ }^{3}$, A.A. QURESHI ${ }^{4}$
}

(Manuscript received 12 August 2011, accepted 25 January 2012)

ABSTRACT Inhalation of indoor radon has been recognized as the largest contributor to the total effective dose received by human beings. Indoor radon data were collected from the dwellings lying on the sedimentary rocks (sandstones, siltstones and clays) of the Murree Formation, Nagri Formation, Dhok Pathan Formation, Mirpur conglomerate and surficial deposits of the Kotli area in Azad Jammu and Kashmir, Pakistan. Radon measurements were made using the passive time-integrated method using Kodak CN-85 Solid-State Nuclear Track Detectors. The radon concentration in dwellings varied from $13 \pm 6 \mathrm{~Bq} \cdot \mathrm{m}^{-3}$ to $185 \pm 23 \mathrm{~B}$. $\mathrm{qm}^{-3}$, with an average of $73 \pm 15 \mathrm{~Bq} \cdot \mathrm{m}^{-3}$. The radon concentration in the Murree Formation, Nagri Formation, river terrace and Dhok Pathan Formation were 89.7 $\pm 16.5,72 \pm 15,68.5$ and $69 \mathrm{~Bq} \cdot \mathrm{m}^{-3}$, respectively. The average value of all the measured concentrations $\left(73 \pm 15 \mathrm{~Bq} \cdot \mathrm{m}^{-3}\right)$ within the framework of this study is more than the world average value of 40 Bq. ${ }^{-3}$ given by UNSCEAR (United Nations Scientific Committee on the Effects of Atomic Radiation, report to the General Assembly, United Nations, New York, 2000) and is within the action level of 200-600 Bq.m ${ }^{-3}$ fixed by the ICRP(International Commission on Radiological Protection, ICRP publication65, Protection against radon at home and at work, 1993). The ambient gamma dose rates both indoors and outdoors in different parts of Kotli were also measured. The average value of gamma absorbed dose rates prevailing in the indoor environment was $131.2 \pm 16.6 \mathrm{nGy} / \mathrm{h}$. The gamma exposure rates recorded outdoors were $35 \%$ lower than in the indoor environment. The measured gamma dose rates have a weak positive correlation with indoor radon concentration. The annual effective dose for inhabitants in Kotli due to radon ranged from 0.32 to $4.7 \mathrm{mSv}^{-1}{ }^{-1}$, with an average value of $1.8 \mathrm{mSv} \cdot \mathrm{y}^{-1}$. This dose is relatively higher than the world mean dose of $1.15 \mathrm{mSv} / \mathrm{y}$. That is explained by the particular geology of the state of Azad Jammu and Kashmir, and the method of construction of the dwellings.

Keywords: Indoor radon / gamma dose rate / CN-85 / geology / Kotli / Azad Jammu and Kashmir

\footnotetext{
Department of Physics, University of Azad Jammu and Kashmir Muzaffarabad, Azad Kashmir, Pakistan.

Institute of Geology, University of Azad Jammu and Kashmir Muzaffarabad, Azad Kashmir, Pakistan.

Physics Division, Pakistan Institute of Nuclear Science and Technology (PINSTECH), P.O. Nilore, Islamabad, Pakistan.

Radiation Research labs, Comsats Inhalation Institute of Information Technology, Islamabad, Pakistan.
} 


\section{Introduction}

A significant contribution to the radioactivity in the body comes from the gaseous decay products of the uranium and thorium radioactive series, namely radon. Radon emanates from different types of rocks and soils. It migrates to the surface through fissures, cracks, joints, fractures and faults (Appleton, 2007; Choubey et al., 1997). Its concentration in the atmosphere depends upon the uranium and/or radium concentrations present in the soils and bedrocks.

The radioactive daughter products of radon attach themselves to dust particles in the air and when radon gas is inhaled densely, ionizing alpha particles emitted by deposited short-lived decay products of radon can interact with biological tissues in the lungs, leading to DNA damage. The lung cancer risk increases linearly with long-term radon exposure. The concentration of radon increases in enclosed spaces such as underground basements, buildings, homes, offices and schools with limited ventilation. People breathing in such an atmosphere inhale air that is rich in radon. It has been estimated that radon and its short-lived progeny contribute approximately $50 \%$ of the dose received by the general population from natural environmental radiation. Thus, measurement of indoor radon levels in human dwellings both in construction of new buildings (prevention) and in existing buildings (mitigation and remediation) is very important from the public health point of view. Many surveys have been conducted in various countries to determine the radon concentration in different types of dwellings and inhabited buildings (Karpinska et al., 2002; Sundal et al., 2004; Reddy et al., 2003; Makelainen et al., 2001; Singh et al., 2004; Singh et al., 2005). In Pakistan various authors have reported the indoor radon concentration in dwellings (Akram et al., 2005; Tufail et al., 1992; Iqbal et al., 2010; Khan et al., 2005; Rahman et al., 2008; Faheem et al., 2008). The correlation between indoor radon and gamma dose rates have been reported by (Fujimoto, 1998; Makelain et al., 2001; Pilkyte et al., 2005). Cosmic and terrestrial radiation are the natural sources for external radiation exposures. The primordial $\left({ }^{238} \mathrm{U},{ }^{40} \mathrm{~K}\right.$ and $\left.{ }^{232} \mathrm{Th}\right)$ and cosmogenic $\left({ }^{3} \mathrm{H},{ }^{7} \mathrm{Be}\right.$ and $\left.{ }^{14} \mathrm{C}\right)$ radionuclides produce natural radiation. The natural background radiation due to the presence of these primordial radionuclides contributes to exposure to human beings (UNSCEAR, 2000). The assessment of the gamma radiation dose from natural sources is also of significance when the duration of occupancy is considered (i.e. typically people spend more than $80 \%$ of their time indoors); indoor exposure becomes even more important. Thus, considering the health hazards associated with radon, it was important to conduct a representative indoor radon concentration measurement survey for the dwellings belonging to the Kotli district, Azad Jammu and Kashmir. An attempt was made to correlate the measured data with the surficial geology and type of the dwelling construction. The gamma dose rates in indoor and 
outdoor air were measured $1 \mathrm{~m}$ above the ground level in a number of locations throughout the study area to assess the radiological hazards due to natural radioactivity associated with rock units, geological formations and building characteristics. The recorded dose rates included both terrestrial and cosmic ray components. This study reports the first set of data on indoor radon concentrations during summer and gamma dose rates in Kotli, Azad Kashmir. The collected data will serve as a baseline reference for further such studies in the future and will also be useful in environmental planning.

\section{Experimental methods}

\subsection{Study area}

The city of Kotli is the headquarters of the Kotli district, State of Azad Jammu and Kashmir, Pakistan, and is located at a distance of $161 \mathrm{~km}$ from Islamabad, the capital city of Pakistan. The district of Kotli is bounded on the east side by the district of Poonch, in the north by the districts of Sudhnoti and Rawalakot, in the south by the district of Bhimber and in the west by the districts of Mirpur and Rawalpindi. The Kotli district is a low to moderate relief hilly area rising gradually north-northeast towards the high mountains of the Poonch district. The average height in eastern and central parts is 1000 meters, whereas the rest of the area is less than 1000 meters in altitude. The River Poonch flows through Kotli. Its climate is sub-humid and sub-tropical, with seasonal fluctuations in temperature and rainfall. The mean maximum and minimum winter and summer temperatures are $18-5{ }^{\circ} \mathrm{C}$ and $38-25^{\circ} \mathrm{C}$, respectively. The famous Tatapani hot water springs are also situated in the Kotli district.

\subsection{Types of dwellings and masonry materials used for construction}

The houses in the study area varied in structure and construction materials used and were classified into two types, i.e. Pucka (concrete) houses and Kucha (mud) houses. The Pucka houses are constructed using cement, bricks, sand and sandstones, and have concrete roofs and cement plaster floors, walls and roofs. In contrast, the Kucha mud-type houses are made of local clays and sandstones with clay and timber roofs. The foundation walls of these houses are made with cut stones bound with mud with empty spaces between the stones, thus favoring the easy entry of radon into the dwellings. The floors and walls of these houses are made of clay plaster with fewer or smaller windows and are thus poorly ventilated.

The Pucka houses which dominantly exist in Kotli city are relatively new compared with the Kucha houses, which exist in the suburbs of Kotli city. The 
bricks of Pucka and Kucha houses are made of clays of the upper Soan Formation, Dhok Pathan Formation and Holocene surficial deposits. The sandstone used in Pucka and Kucha houses is from the Tertiary molasse sediments. The aggregate used in concrete of Pucka houses includes sandstone, cherty dolomite, limestone and conglomerate aggregates. The sandstone aggregate is from the Murree, Kamlial and Nagri Formations. The cherty dolomite and limestone aggregates are from the Proterozoic Muzaffarabad Formation and the Paleocene-Eocene Patala and Margalla Hill Formations, respectively. However, people also use the limestone aggregate from the Margalla Hills of Pakistan. The conglomerate aggregate is from the Mirpur conglomerate, upper part of Dhok Pathan, Soan Formation, Poonch River and stream deposits. The sand used in concrete and plaster is from Lawrencepur, Poonch River and local streams.

\subsection{Geology}

The area of Kotli lies in the sub-Himalayas of Kashmir, Pakistan. The Precambrian to Cenozoic sedimentary cover sequence of the Indian plate is folded and imbricated during the Tertiary Himalayan collision (Baig, 1991; Wadia, 1931). The cyclic clays, siltstones and sandstones of the Murree, Kamlial, Chingi, Nagri and Dhok Pathan Formations are the Tertiary molasse sediments of the Himalayas (Akhter et al., 2004; Moughal et al., 2004; Wadia, 1928; Fig. 1). The Miocene Murree and Kamlial Formations are emplaced along the active Himalayan collision zone Riasi Thrust (Kotli Thrust or Himalayan Frontal Thrust); (Wadia, 1928) on the Late Miocene-Early Pliocene Dhok Pathan Formation. The soil porosity, fold axes, cracks, fissures, fractures, joints and faults provide natural pathways for migration of radon gas from the subsurface to the earth's surface. The structure and bedrock geology have a significant correlation with the variation in radon concentration (Ramola et al., 2005; Karpinska et al., 2002; Sundal et al.,2004).

\subsection{Indoor radon measurements}

In the present work, Kodak CN-85 Solid-State Nuclear Track Detectors (SSNTD) in plastic dosimeters were used to determine the radon concentration (Fleischer et al., 1975) in dwellings of the Kotli area, State of Azad Jammu and Kashmir. The dosimeter is a simple rectangular container, basically a diffusion chamber with an area of $3.5 \times 3.5 \mathrm{~cm}^{2}$ equipped with SSNTD (Fig. 2). The sheets of the Kodak CN85 detectors were cut into pieces $1 \mathrm{~cm}^{2}$ and designed for installation in the dosimeters. The dosimeters as well as the enclosed Kodak CN-85 detectors were properly labeled for their identification. The dosimeters were installed for 60 days of exposure in bedrooms, drawing rooms and kitchens of houses in the summer 


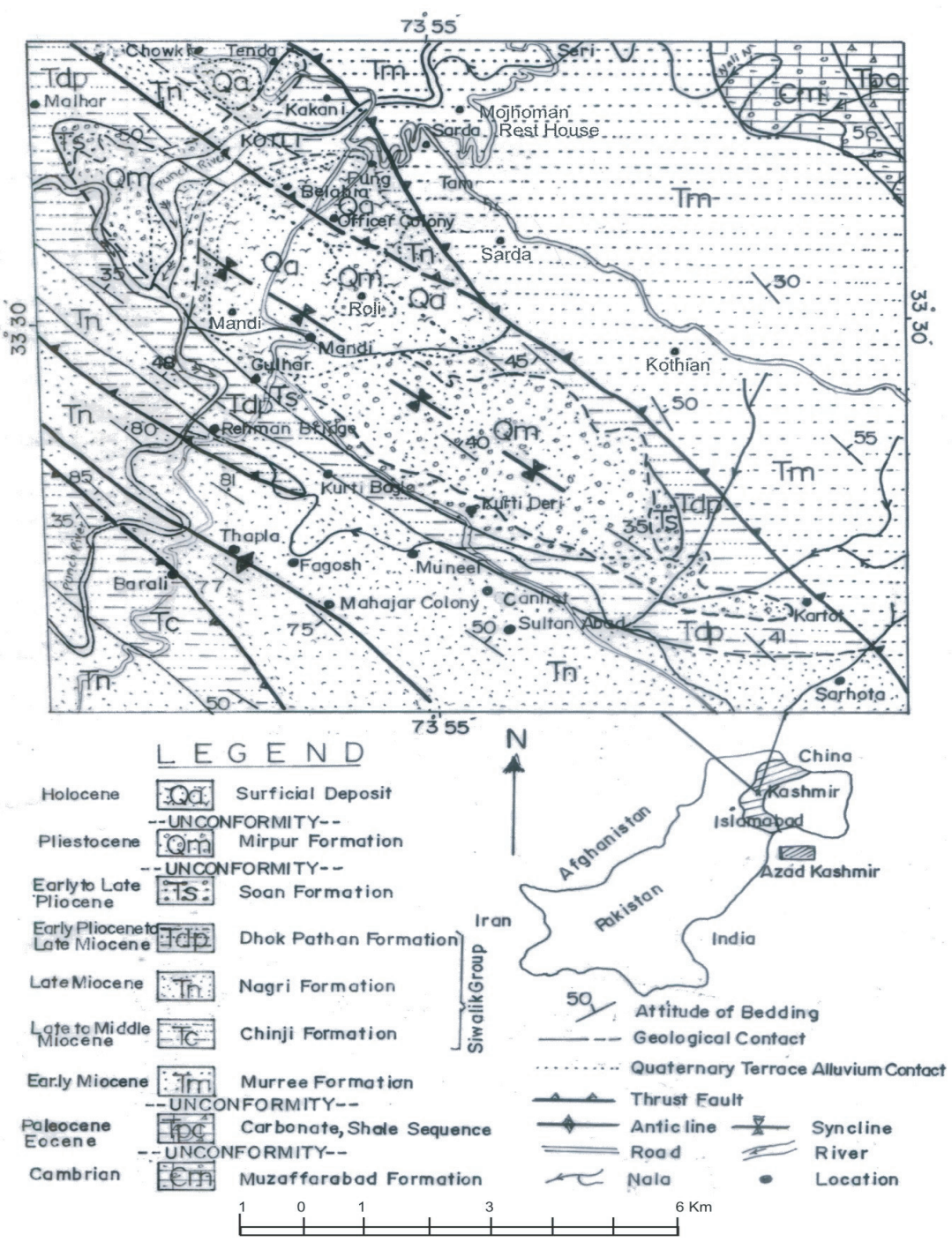

Figure 1 - Geological Map showing dosimeter location in dwellings of Kotli \& Surrounding areas, Azad Kashmir Pakistan. Modified after Akhtar et al., 2004 and Mughal et al., 2004. 


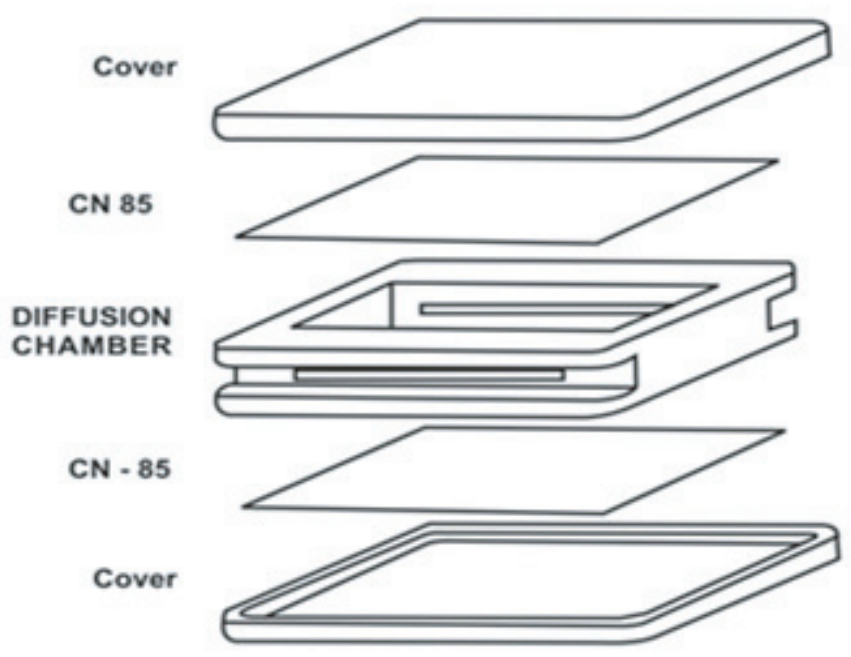

Figure 2 - Box type dosimeter consisting two CN-85 detectors employed for radon measurements in dwelling of kotli area, Azad Kashmir.

season during the months of July through September. After exposure for 60 days, the detectors were detached and etched chemically in $6 \mathrm{~N} \mathrm{NaOH}$ solution for 10 minutes. The etched detectors were cleaned ultrasonically to remove dust particles from the detectors' surface. Track density was measured using a Zeiss optical microscope at 400x magnification. The track density was then converted into radon concentration $\left(\mathrm{Bq} . \mathrm{m}^{-3}\right.$ ) by applying the conversion factor for Kodak $\mathrm{CN}-85$ detectors in the box-type dosimeters as 0.0009 tracks $\mathrm{cm}^{-2} \cdot \mathrm{h}^{-1}$ equals 1 Bq.m ${ }^{-3}$ of radon (Iqbal et al., 2008; Akram et al., 2005; Tufail et al., 1992). The information about types of houses, geology and construction aggregates was collected for possible correlation with the radon concentration in the dwellings of the Kotli area. From the averaged radon concentration, the annual effective dose $D$ $\left(\mathrm{mSv} \cdot \mathrm{y}^{-1}\right)$ to inhabitants of Kotli due to radon was estimated using the following relationship suggested by UNSCEAR (UNSCEAR 2000):

$$
\begin{aligned}
& D=C R \mathrm{n} \times F \times T \times D, \text { where } \\
& D=\text { Annual effective dose rate indoors in } \mathrm{mSv} \cdot \mathrm{y}^{-1} \\
& C R \mathrm{n}={ }^{222} \mathrm{Rn} \text { concentration (in } \mathrm{Bq} \cdot \mathrm{m}^{-3} \text { ) } \\
& F={ }^{222} \mathrm{Rn} \text { equilibrium factor indoor, }
\end{aligned}
$$


$T=$ indoor occupancy time, and

$D=$ the dose conversion factor.

The values for the occupancy factor, equilibrium equivalent factor and dose conversion factor mentioned in (UNSCEAR report of 2000) were adopted for the calculation of the average annual effective dose.

\subsection{Gamma radiation measurements}

The ambient indoor and outdoor gamma survey measurements were taken in air one meter above the ground at different locations (Table III) using a portable radiometric instrument, a Ludlum 19 Micro R Meter, which utilizes an internally mounted $\mathrm{Na}$ I (TI) scintillator for measuring gamma radiation. The exposure rate measured in $\mu \mathrm{R} \cdot \mathrm{h}^{-1}$ was converted into the absorbed dose rate $\mathrm{nGy} \cdot \mathrm{h}^{-1}$ using the conversion factor of $\mu \mathrm{R} \cdot \mathrm{h}^{-1}=8.7 \mathrm{nGy} \cdot \mathrm{h}^{-1}$. The readings are represented in terms of $n G y \cdot h^{-1}$. The absorbed gamma doses were calculated from the measured exposure rates by adopting the values of the conversion coefficient from the absorbed dose in air to the effective dose received by adults, occupation factor 0.2 for outdoors and 0.8 for indoors, to convert the absorbed dose in air into the annual effective dose for an adult, as proposed by UNSCEAR (UNSCEAR, 2000).

\section{Results and discussion}

The radon data were measured in the dwellings overlapping the tertiary sedimentary molasses of the Kotli area, as shown in (Tab. I, Fig. 1). The radon data of these dwellings varied from $13 \pm 6 \mathrm{~Bq} \cdot \mathrm{m}^{-3}$ to $185 \pm 23 \mathrm{~Bq} \cdot \mathrm{m}^{-3}$, with an average of $72.9 \pm 15$ Bq. $\mathrm{m}^{-3}$. Pucka and Kucha dwellings have an average radon concentration of $71 \pm 15 \mathrm{~Bq} \cdot \mathrm{m}^{-3}$ and $75 \pm 16 \mathrm{~Bq} \cdot \mathrm{m}^{-3}$, respectively. The houses with basement floors made of concrete and with good ventilation had lower radon levels than Kucha houses, which featured earthen basement floors, with poor ventilation.

The foundations of Kucha dwellings are laid on crushed stones and the foundation walls are made with cut stones bound with mud. These foundations had empty spaces between the stones, thus favoring the easy entry of radon into the dwellings. The restricted ventilation in the Kucha dwellings may be one of the possible reasons for the accumulation of radon in these types of houses.

The average value of the radon concentration in kitchens was higher than its value in bedrooms and drawing rooms. The bedrooms of Kucha dwellings showed a higher average radon concentration, $83.1 \mathrm{~Bq} \cdot \mathrm{m}^{-3}$, as compared with the 67.1 Bq. $\mathrm{m}^{-3}$ in bedrooms of Pucka houses. This higher value of radon concentration in Kucha houses can again be attributed to poor ventilation and 
TABLE I

The radon concentration levels in the dwellingsof theKotli area, Azad Jammu and Kashmir.

\begin{tabular}{|c|c|c|c|c|c|}
\hline S/no & Location & $\begin{array}{l}\text { Number of } \\
\text { measurements }\end{array}$ & $\begin{array}{l}\text { Radon concentration } \\
\text { (Average value) }\left(\text { Bq. } \mathrm{m}^{-3}\right)\end{array}$ & $\begin{array}{l}\text { Annual effective } \\
\text { Dose } \\
\left(\mathrm{mSv} \cdot \mathrm{y}^{-1}\right)\end{array}$ & $\begin{array}{l}\text { Geological } \\
\text { Formation }\end{array}$ \\
\hline \multicolumn{6}{|c|}{ Pucka dwellings } \\
\hline 1 & $\begin{array}{l}\text { Mohallah sultan } \\
\text { abad }\end{array}$ & 4 & $\begin{array}{l}58.3 \pm 14 \\
(26 \pm 12-110 \pm 17)\end{array}$ & $\begin{array}{l}01.46 \\
(0.65-2.77)\end{array}$ & Nagri \\
\hline 2 & Kurtibagla & 4 & $\begin{array}{l}74.5 \pm 15 \\
(40 \pm 13-97 \pm 18)\end{array}$ & $\begin{array}{l}1.87 \\
(1.0-2.44)\end{array}$ & Dhokpathan \\
\hline 3 & $\begin{array}{l}\text { Kalar colony } \\
\text { Kothain }\end{array}$ & 4 & $\begin{array}{l}73.4 \pm 14 \\
(55 \pm 13-103 \pm 17)\end{array}$ & $\begin{array}{l}1.84 \\
(1.38-2.59)\end{array}$ & Nagri \\
\hline 4 & Sarda & 2 & $\begin{array}{l}108.5 \pm 16 \\
(87 \pm 17-130 \pm 18)\end{array}$ & $\begin{array}{l}2.73 \\
(2.19-3.27)\end{array}$ & Murree \\
\hline 5 & Tungrote & 2 & $\begin{array}{l}82.5 \pm 16 \\
(68 \pm 15-97 \pm 18)\end{array}$ & $\begin{array}{l}2.1 \\
(1.71-2.44)\end{array}$ & Murree \\
\hline 6 & Danna numb & 2 & $\begin{array}{l}126.5 \pm 18 \\
(69 \pm 14-185 \pm 23)\end{array}$ & $\begin{array}{l}3.2 \\
(1.73-4.66)\end{array}$ & Nagri \\
\hline 7 & Kotli city & 2 & $\begin{array}{l}62.7 \pm 14 \\
(29 \pm 10-87 \pm 17)\end{array}$ & $\begin{array}{l}1.57 \\
(0.73-2.19)\end{array}$ & River terrace \\
\hline 8 & $\begin{array}{l}\text { Housing } \\
\text { Scheme }\end{array}$ & 4 & $\begin{array}{l}53.3 \pm 13 \\
(35 \pm 1168 \pm 15)\end{array}$ & $\begin{array}{l}1.34 \\
(0.88-1.71)\end{array}$ & River terrace \\
\hline 9 & Jandarlan & 2 & $74 \pm 15$ & 1.86 & Nagri \\
\hline 10 & MandiPiran & 5 & $\begin{array}{l}89.5 \pm 16 \\
(23 \pm 9-122 \pm 20)\end{array}$ & $\begin{array}{l}2.3 \\
(0.57-3.1)\end{array}$ & River terrace \\
\hline 11 & $\begin{array}{l}\text { Mahajar colony } \\
\text { Fagosh }\end{array}$ & 2 & $\begin{array}{l}44 \pm 12 \\
74 \pm 15\end{array}$ & $(0.93-1.26)$ & Nagri \\
\hline 12 & Majhoman & 4 & $\begin{array}{l}56.3 \pm 12 \\
(13 \pm 6-87 \pm 17)\end{array}$ & $\begin{array}{l}1.41 \\
(0.32-2.19)\end{array}$ & Murree \\
\hline 13 & ManeelMalakai & 4 & $\begin{array}{l}81 \pm 16 \\
(68 \pm 15-93 \pm 17)\end{array}$ & $\begin{array}{l}2.02 \\
(1.71-2.34)\end{array}$ & Nagri \\
\hline 14 & Chattarfagosh & 4 & $\begin{array}{l}59 \pm 15 \\
(32 \pm 16-100 \pm 18)\end{array}$ & $\begin{array}{l}1.49 \\
(0.47-2.52)\end{array}$ & NagriFormation \\
\hline 15 & $\begin{array}{l}\text { University } \\
\text { College }\end{array}$ & 4 & $\begin{array}{l}63.5 \pm 14 \\
(35 \pm 11-80 \pm 16)\end{array}$ & $\begin{array}{l}1.6 \\
(0.88-2.01)\end{array}$ & Dhokpathan \\
\hline \multicolumn{6}{|c|}{ Average radon concentration pucka houses $=71.28 \pm 15(13 \pm 6$ to $185 \pm 23)$ Bq. $\mathrm{m}^{-3}$} \\
\hline \multicolumn{6}{|c|}{ Kucha dwellings } \\
\hline 16 & Dunginar & 2 & $80 \pm 16$ & 2.01 & Nagri \\
\hline 17 & Danna colony & 2 & $\begin{array}{l}41 \pm 12 \\
(39 \pm 13-42 \pm 12)\end{array}$ & $\begin{array}{l}1.97 \\
(0.9-1.05)\end{array}$ & Nagri \\
\hline 18 & Danna Numb & 2 & $\begin{array}{l}101.5 \pm 18 \\
(100 \pm 18-103 \pm 17)\end{array}$ & $\begin{array}{l}2.5 \\
(2.53-2.59)\end{array}$ & Nagri \\
\hline 19 & Maneel & 4 & $\begin{array}{l}64.8 \pm 14 \\
(42 \pm 12-122 \pm 20)\end{array}$ & $\begin{array}{l}1.6 \\
(1.05-3.07)\end{array}$ & nagri \\
\hline
\end{tabular}


TABLE I (continued).

\begin{tabular}{|c|c|c|c|c|c|}
\hline S/no & Location & $\begin{array}{l}\text { Number of } \\
\text { measurements }\end{array}$ & $\begin{array}{l}\text { Radon concentration } \\
\text { (Average value) }\left(\text { Bq. } \mathrm{m}^{-3} \text { ) }\right.\end{array}$ & $\begin{array}{l}\text { Annual effective } \\
\text { Dose } \\
\left(\mathrm{mSv} \cdot \mathrm{y}^{-1}\right)\end{array}$ & $\begin{array}{l}\text { Geological } \\
\text { Formation }\end{array}$ \\
\hline 20 & Fagoshtapla & 4 & $\begin{array}{l}74 \pm 15 \\
(42 \pm 12-106 \pm 18)\end{array}$ & $\begin{array}{l}1.86 \\
(1.05-2.67)\end{array}$ & Nagri \\
\hline 21 & BukhanNavni & 4 & $\begin{array}{l}76.7 \pm 16 \\
(13 \pm 9-112 \pm 22)\end{array}$ & $\begin{array}{l}1.91 \\
(0.5-2.83)\end{array}$ & Nagri \\
\hline 22 & Jandralan & 2 & $\begin{array}{l}81 \pm 15.5 \\
(55 \pm 13-107 \pm 18)\end{array}$ & $\begin{array}{l}2.03 \\
(1.38-2.69)\end{array}$ & Nagri \\
\hline 23 & Central Bukhan & 4 & $\begin{array}{l}66 \pm 14.7 \\
(42 \pm 13-100 \pm 18)\end{array}$ & $\begin{array}{l}1.7 \\
(1.05-2.52)\end{array}$ & Nagri \\
\hline 24 & BukhanKala & 4 & $\begin{array}{l}77.3 \pm 15 \\
(64 \pm 14-87 \pm 17)\end{array}$ & $\begin{array}{l}1.94 \\
(1.61-2.19)\end{array}$ & Nagri \\
\hline 25 & Central Maneel & 3 & $\begin{array}{l}84 \pm 14.6 \\
(55 \pm 13-115 \pm 16)\end{array}$ & $\begin{array}{l}2.11 \\
(1.38-2.89)\end{array}$ & Nagri \\
\hline 26 & ManeelKatha & 4 & $\begin{array}{l}73.7 \pm 15.7 \\
(46 \pm 12-87 \pm 17)\end{array}$ & $\begin{array}{l}1.85 \\
(1.15-2.19)\end{array}$ & Nagri \\
\hline 27 & Sirind & 2 & $\begin{array}{l}96.5 \pm 17.5 \\
(71 \pm 15-122 \pm 20)\end{array}$ & $\begin{array}{l}2.42 \\
(1.78-3.1)\end{array}$ & Nagri \\
\hline
\end{tabular}

Average radon concentration kucha houses $=75.1 \pm 16(23 \pm 9$ to $122 \pm 20) \mathrm{Bqm}^{-3}$

Overall average radon concentration $=72.93 \pm 15(13 \pm 6$ to $185 \pm 23)$ Bq. ${ }^{-3}$.

Overall average annual effective dose due to radon $=0.32$ to $4.66 \mathrm{mSv} \cdot \mathrm{y}^{-1}$.

cracks in the floors of Kucha houses. The higher radon levels in Kucha (mud) houses compared with the Pucka (cemented) houses have also been reported in the literature (Singh et al., 2005; Reddy et al., 2003; Khan et al., 2008). The indoor radon concentrations classified according to the geological substrate on which dwellings rest are presented in Tables I and II.

The dwellings situated in the Dhok Pathan Formation and river terrace lithology had similar average radon concentration values of $69 \mathrm{~Bq} \cdot \mathrm{m}^{-3}(35 \pm 11$ to $97 \pm 18$ Bq. $\left.\mathrm{m}^{-3}\right)$ and $68.5 \mathrm{~Bq} \cdot \mathrm{m}^{-3}\left(23 \pm 9\right.$ to122 $\left.\pm 20 \mathrm{~Bq} \cdot \mathrm{m}^{-3}\right)$, respectively. In the Nagri Formation and Murree Formation, the average radon concentrations recorded were $72 \pm 15$ Bq.m ${ }^{-3}\left(19 \pm 8\right.$ to $185 \pm 23$ Bq.m ${ }^{-3}$ ) and $89.7 \pm 16.5$ Bq.m ${ }^{-3}$ (64 \pm 14 to $130 \pm 18 \mathrm{~Bq} \cdot \mathrm{m}^{-3}$ ), respectively (Tab. II).

Although the size of samples for the Murree Formation is relatively smaller, a high average radon concentration was recorded in dwellings situated in this formation. The high average concentration in dwellings located in the Murree Formation may be attributed to the closeness of dwellings to the active Riasi Thrust (Sarda Fault). The active fault provides passage for radon to the surface through ruptures, cracks and fractures. The lithology of the Murree Formation 
A. IQBAL et al.

TABLE II

Radon Concentration in dwellings in different geological formations of Kotli, Azad Jammu \& Kashmir, Sub-Himalyas, Pakistan.

\begin{tabular}{lll}
\hline S. No. & Rock Units & Average Rn concentration $\left(\mathbf{B q} \cdot \mathbf{m}^{-\mathbf{3}}\right)$ \\
\hline 1. & Murree Formation & $89.7 \pm 16.5(64 \pm 14-130 \pm 18)$ \\
2. & Nagri Formation & $72 \pm 15(19 \pm 8-185 \pm 23)$ \\
3. & Dhok Pathan Formation & $69(35 \pm 11-97 \pm 18)$ \\
4. & River Terrace & $68.5(23 \pm 9-122 \pm 20)$ \\
\hline
\end{tabular}

consists of gray fractured and jointed sandstones alternating with red impervious clays. Fractures in the bedrock formation and cracks in the soil may be a cause of high radon entry rates into dwellings and thus the higher indoor radon concentration.

The highest value of $185 \pm 23$ Bq. $\mathrm{m}^{-3}$ was recorded locally in the Nagri Formation. The late Miocene Nagri Formation in the footwall of the Riasi Fault consists of alternating sandstones and clays. The sandstone to clay ratio is 60 to $40 \%$. This Siwalik group of geological formation presents a higher uranium content than other lithological units (Khan et al., 2005). Figure 3 shows the frequency distribution of radon concentration in dwellings. Radon concentrations in the ranges $0-25,26-50,51-75,76-100,101-125,126-150,151-175$ and 176$200 \mathrm{~Bq} \cdot \mathrm{m}^{-3}$ were $5 \%, 21 \%, 30 \%, 30 \%, 12 \%, 2 \%, 0 \%$ and $1 \%$, respectively. This indicated that nearly $72 \%$ of dwellings had radon concentrations in the range between 51 and 125 Bq. $\mathrm{m}^{-3}$. The average value of the radon concentration in this work is higher than the world average of $40 \mathrm{~Bq} \cdot \mathrm{m}^{-3}$ (UNSCEAR, 2000). The radon

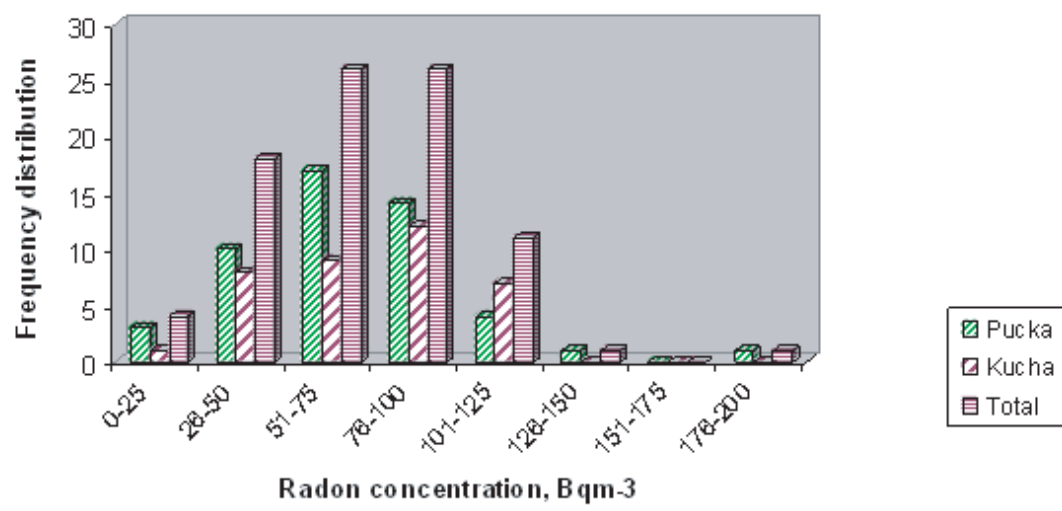

Figure 3 - Frequency Distribution of Radon in dwellings of Kotli area (Azad Kashmir) Pakistan. 
concentration in masonry dwellings of the Kotli area is influenced by the association of several parameters, mainly:

(1) Cracks in the floors, which may enhance the effects of temperature and pressure differentials on conductive transport of radon, (2) gaps at the wall-floor junction, (3) the rate of exchange between indoor and outdoor air, which depends on ventilation, (4) the amount of uranium in the substrate soils and underlying rocks, (5) the materials used to construct walls and floors, and (6) inhomogeneities in the foundations of Kucha houses, which may be a cause of possible higher radon exposure.

The summer indoor radon concentration range in the present study is higher than similar data from Skardu (76 to 152.4 Bq. ${ }^{-3}$, Akram et al., 2005), Islamabad (11-78 Bq. ${ }^{-3}$, Rahman et al., 2008) in Pakistan and Assam (39 to 141 Bq. ${ }^{-3}$, Deka et al., 2003), Kumaum Himalyas (10 to 20 Bq.m ${ }^{-3}$, Ramola et al., 2005), Khamam, AndhraPredesh (16 to 83 Bq. ${ }^{-3}$, Reddy et al., 2003) and Malwa Punjab (54 to $151 \mathrm{~Bq} . \mathrm{m}^{-3}$, Singh et al., 2005b), areas of India. However, the indoor radon concentration values obtained in the present study are lower than the radon range reported for Mirpur, Azad Kashmir, Pakistan (14 \pm 7 to $258 \pm 28$ Bq. ${ }^{-3}$ Iqbal et al., 2008), Hamadan, Iran (81 to 257 Bq.m ${ }^{-3}$, Gillmore et al., 2010), Hamirpur district, India (260.51 to 724.29 Bq.m ${ }^{-3}$, Singh et al., 2005a) and northern areas of India $\left(19.4 \pm 1.9-2782.6 \pm 23.7\right.$ Bq. ${ }^{-3}$, Khan et al., 2008).The differences in radon concentrations observed between the present results and other findings can be attributed to differences in climatic conditions, geological parameters, the housing construction patterns and the different detectors used.

The present results can be compared with the radon concentration in dwellings of the other cities of Pakistan as reported in the literature. The indoor radon concentration has been reported to range from 40 to $173 \mathrm{~Bq} \cdot \mathrm{m}^{-3}$ and 38 to $193 \mathrm{~Bq} \cdot \mathrm{m}^{-3}$ (Faheem et al., 2008) for living rooms and bedrooms, respectively, for various districts of Punjab,while in the city of Rawalpindi the indoor radon concentration values have been reported to range between (31 to 213) Bq. $\mathrm{m}^{-3}$ and (27 to 143) Bq. $\mathrm{m}^{-3}$ (Khan et al., 2005) in old buildings and new buildings, respectively. The difference in our radon values and those of Faheem et al. (2008) and Khan et al. (2005) may be due to different geological parameters, housing patterns, climatic conditions, construction material and the different types of detectors used. Only one radon measurement $\left(185 \pm 23 \mathrm{~Bq} \cdot \mathrm{m}^{-3}\right)$ above the US EPA limit of $148 \mathrm{~Bq} \cdot \mathrm{m}^{-3}$ was found. The range of indoor radon concentration (13 \pm 6 Bq. $\mathrm{m}^{-3}$ to $185 \pm 23 \mathrm{~Bq} \cdot \mathrm{m}^{-3}$ ) is lower than the guidelines for the indoor radon action level of 200-600 Bq. ${ }^{-3}$ set by the ICRP ( ICRP, 1993).The average value of the radon concentration in this study is, however, higher than the world average of $40 \mathrm{~Bq} \cdot \mathrm{m}^{-3}$ (UNSCEAR, 2000). 
The indoor annual effective dose due to radon for the inhabitants of the Kotli area is given in Table I. The mean value was estimated as $1.8 \mathrm{mSv}^{-1} \mathrm{y}^{-1}$ with a range variation from $0.32 \mathrm{mSv}^{-1} \mathrm{y}^{-1}$ to $4.6 \mathrm{mSv}^{-1} \mathrm{y}^{-1}$ This result is within the ICRP recommended action level of 3-10 mSv. ${ }^{-1}$ (ICRP 65, 1993) but higher than the world average dose value of $1.15 \mathrm{mSv}^{-1} \mathrm{y}^{-1}$ (UNSCEAR, 2000). The present study was conducted in the summer months for exposition from June to August when house owners keep the windows and doors mostly open for ventilation. The topography and climate of the Kotli area is such that it is cold in winter, suggesting that the radon concentration in dwellings could be higher due to reduced ventilation. It is recommended that a further extensive study of indoor radon measurements in the Kotli area in winter (November through February) should be carried out to calculate the annual absorbed dose, since the influence of the winter radon concentration on the dose could be larger.

\subsection{Gamma dose rates}

The gamma radiation levels indoors and outdoors were measured in various parts of the Kotli area and the results of gamma dose rates in air in outdoor and indoor environs are presented in Table III. The outdoor gamma dose rates varied from 69 to $121 \mathrm{nGy} \cdot \mathrm{h}^{-1}$ with an average arithmetic value of $97.1 \pm 13.4 \mathrm{nGy} \cdot \mathrm{h}^{-1}$ and a geometric mean value of $96.1 \mathrm{nGy} \cdot \mathrm{h}^{-1}$. The average value of the gamma dose rates prevailing in indoor environs was $131.2 \pm 16 . \mathrm{nGy}^{-1} \mathrm{~h}^{-1}(104$ to 165$) \mathrm{nGy} \cdot \mathrm{h}^{-1}$ with a geometric mean value of $110.3 \mathrm{nGy} \cdot \mathrm{h}^{-1}$. The gamma dose rates in the area depend on the lithologies (sandstones and clays), and radionuclide distributions in underlying soil and substrate rock units. The ratio of indoor to outdoor gamma radiation in the present study is found to be 1.35 , which is slightly lower than the world average value of 1.4 given by UNSCEAR (UNSCEAR, 2000), except for uncertainties. The gamma dose rates recorded indoors were $35 \%$ higher than in the outdoor environs. The range of indoor gamma dose rates obtained in the present study in Kotli was similar to the 113.1 to $243.6 \mathrm{nGy} \cdot \mathrm{h}^{-1}$ for Manisa, Turkey (Erees et al.,2005) and lies towards the higher side compared with studies reported for the Kastamonu region, Nothern Turkey (44.9 to $68.5 \mathrm{nGy} \cdot \mathrm{h}^{-1}$, Kam and Bozkurt, 2007) and Tekirdag, Turkey (30.5 to $68.6 \mathrm{nGy} \cdot \mathrm{h}^{-1}$, Yarar and Kam, 2005). However, the indoor gamma dose rate range of (104 to 165$) \mathrm{nGy} \cdot \mathrm{h}^{-1}$ in the Kotli area is appreciably higher than the world estimates for the population-weighted average range of 18 to $93 \mathrm{nGy} \cdot \mathrm{h}^{-1}$, UNSCEAR (2000).

Figure 4 shows the frequency distribution of gamma dose rates in outdoor and indoor environments. Outdoor gamma dose rates in the ranges 0-100, 101-125 and $126-150 \mathrm{nGy}^{-1}$ were $66 \%, 29 \%$ and $3.7 \%$, respectively, whereas indoor gamma dose rates in the ranges $0-100,101-125$ and $126-150 \mathrm{nGy}^{-1} \mathrm{~h}^{-1}$ were $66 \%$, 
TABLE III

Indoor and outdoor gamma dose rates in Kotli (Azad Kashmir), Pakistan.

\begin{tabular}{|c|c|c|c|c|c|c|c|c|}
\hline \multirow[t]{2}{*}{$\begin{array}{l}\text { Sample } \\
\text { No. }\end{array}$} & \multirow[t]{2}{*}{ Location } & \multirow[t]{2}{*}{$\begin{array}{l}\text { House } \\
\text { Type }\end{array}$} & \multicolumn{4}{|c|}{$\begin{array}{c}\text { Gamma Dose }\left(\mathrm{nGy} \cdot \mathrm{h}^{-1}\right) \text { Annual effective } \\
\text { Gamma Dose } \\
\left(\mathbf{m S v} \cdot \mathbf{y}^{-1}\right)\end{array}$} & \multirow[t]{2}{*}{ Rock unit } & \multirow[t]{2}{*}{ Lithology } \\
\hline & & & Outdoor & Indoor & Outdoor & Indoor & & \\
\hline G1 & Sarda Rest House & Pucka & 95 & 147 & 0.11 & 0.72 & $\begin{array}{l}\text { Murree } \\
\text { Formation }\end{array}$ & $\begin{array}{l}\text { Gray sandstone } \\
\text { subordinate red } \\
\text { clays }\end{array}$ \\
\hline G3 & Kothian Check & “ & 95 & 139 & 0.11 & 0.68 & “ & “ \\
\hline \multirow[t]{4}{*}{ G4 } & Mahjuman & “ & 95 & 113 & 0.11 & 0.55 & “ & “ \\
\hline & Sarda & Kucha & 113 & 130 & 0.13 & 0.63 & “ & $\begin{array}{l}\text { Gray sandstone } \\
\text { alternating with } \\
\text { red clays }\end{array}$ \\
\hline & Mahjuman & $\begin{array}{l}\text { Kucha } \\
\text { Mud }\end{array}$ & 121 & 165 & 0.14 & 0.80 & “ & “ \\
\hline & Mahjuman & $\begin{array}{l}\text { Semi- } \\
\text { Kucha }\end{array}$ & 104 & 147 & 0.12 & 0.72 & “ & “" \\
\hline \multirow[t]{2}{*}{ G2 } & Sarda & Kucha & 113 & 130 & 0.13 & 0.63 & “ & “" \\
\hline & Kothian & Kucha & 95 & 165 & 0.11 & 0.80 & & \\
\hline G6 & Tinda Rest House & Pucka & 95 & 104 & 0.11 & 0.51 & $\begin{array}{l}\text { Mirpur } \\
\text { Formation }\end{array}$ & $\begin{array}{l}\text { Conglomerates } \\
\text { sand silt and } \\
\text { clay }\end{array}$ \\
\hline G8 & BilhyaMohallah & “ & 113 & 139 & 0.13 & 0.68 & “ & “ \\
\hline G12 & RoliEidgah & " & 95 & 147 & 0.11 & 0.72 & " & “" \\
\hline G13 & RoliKhas & Pucka & 78 & 130 & 0.09 & 0.63 & “ & “ \\
\hline G14 & RoliKanghar & “ & 69 & 130 & 0.08 & 0.63 & & “" \\
\hline G19 & Muneel & Pucka & 78 & 113 & 0.09 & 0.55 & $\begin{array}{l}\text { Nagri } \\
\text { Formation }\end{array}$ & \\
\hline G20 & Kanat & “ & 95 & 121 & 0.11 & 0.59 & “" & \\
\hline G21 & $\begin{array}{l}\text { Mahjar colony } \\
\text { Fagosh }\end{array}$ & “ & 104 & 121 & 0.12 & 0.59 & " & \\
\hline G22 & Fagosh & “ & 95 & 113 & 0.11 & 0.55 & “ & \\
\hline G18 & Muneel & Kucha & 78 & 130 & 0.09 & 0.63 & “ & \\
\hline \multirow[t]{2}{*}{ G24 } & Bundial & " & 104 & 147 & 0.12 & 0.72 & "“ & \\
\hline & Fagosh & " & 104 & 156 & 0.12 & 0.76 & “ & \\
\hline G5 & Tungrote & Pucka & 87 & 113 & 0.1 & 0.55 & $\begin{array}{l}\text { RiverTerrace } \\
\text { Footwall of } \\
\text { Riasi Thrust }\end{array}$ & \\
\hline G9 & BillyyaMohallah & “ & 127 & 130 & 0.15 & 0.63 & “ & \\
\hline
\end{tabular}


TABLE III (continued).

\begin{tabular}{|c|c|c|c|c|c|c|c|c|}
\hline \multirow[t]{2}{*}{$\begin{array}{l}\text { Sample } \\
\text { No. }\end{array}$} & \multirow[t]{2}{*}{ Location } & \multirow[t]{2}{*}{$\begin{array}{l}\text { House } \\
\text { Type }\end{array}$} & \multicolumn{2}{|c|}{ Gamma Dose $\left(n G y \cdot h^{-1}\right)$} & \multicolumn{2}{|c|}{$\begin{array}{l}\text { Annual effective } \\
\text { Gamma Dose } \\
\left(\mathbf{m S v} \cdot \mathbf{y}^{-1}\right)\end{array}$} & \multirow[t]{2}{*}{ Rock unit } & \multirow[t]{2}{*}{ Lithology } \\
\hline & & & Outdoor & Indoor & Outdoor & Indoor & & \\
\hline G10 & MandiPiran & “ & 95 & 113 & 0.11 & 0.55 & “ & \\
\hline G11 & $\begin{array}{l}\text { Officer Colony } \\
\text { Kotli }\end{array}$ & “ & 87 & 104 & 0.10 & 0.51 & “ & “ \\
\hline G15 & Gnehar & Pucka & 78 & 130 & 0.09 & 0.63 & DhokPathan & $\begin{array}{l}\text { Sandstone } \\
\text { alternating } \\
\text { with clays }\end{array}$ \\
\hline G16 & KurtiDehri & “ & 87 & 113 & 0.10 & 0.55 & “ & “ \\
\hline G17 & KurtiBungla & “ & 95 & 130 & 0.11 & 0.63 & “ & “ \\
\hline G7 & Thalhaire & “ & 113 & 139 & 0.13 & 0.68 & “ & $\begin{array}{l}\text { Conglomerate } \\
\text { sand silt and } \\
\text { clay }\end{array}$ \\
\hline \multirow[t]{2}{*}{ G7-1 } & “ & Kucha & 113 & 147 & 0.13 & 0.72 & “ & $\begin{array}{l}\text { Gray to } \\
\text { yellowish gray } \\
\text { friable course } \\
\text { grain sheard } \\
\text { sandstone } \\
\text { overlain by } \\
\text { quaternary } \\
\text { alluvium } \\
\text { conglomerates } \\
\text { sand silt and } \\
\text { clay }\end{array}$ \\
\hline & & & & Average: & 0.11 & 0.64 & & \\
\hline
\end{tabular}

Outdoor gamma absorbed dose rates: Mean value $97.06 \pm 13.38$ (69-121) nGy. $\mathrm{h}^{-1}$.

Indoor gamma absorbed dose rates: Mean value $131.24 \pm 16.61(104-165) \mathrm{nGy} \cdot \mathrm{h}^{-1 \mathrm{~s}}$

$29 \%$ and $3.7 \%$, respectively. The average values of gamma dose rates in indoor environments were $128.7 \pm 15.55,131.8 \pm 11.33,133.4 \pm 8.8$ and $142 \pm$ $16.8 \mathrm{nGy} \cdot \mathrm{h}^{-1}$ in the Nagri Formation, Dhok Pathan Formation, Mirpur Formation and Murree Formation, respectively. On the other hand, the average values of the gamma dose rate in the outdoor environs were recorded as $90 \pm 15.3,94 \pm 10.8$, $97.2 \pm 14$ and $103.9 \pm 9.87 \mathrm{nGy} \cdot \mathrm{h}^{-1}$ in the Mirpur Formation, Nagri Formation, Dhok Pathan Formation and Murree Formation, respectively. The highest average values of gamma dose rates both in indoor and outdoor environs were recorded in the Murree Formation. In the present study, the highest mean indoor ${ }^{222} \mathrm{Rn}$ concentration and mean gamma dose rate were obtained in the same lithological formation (Murree Formation).

Table III gives the average values of the annual effective dose (indoor and outdoor) in the Kotli area due to gamma exposure. The average annual effective 


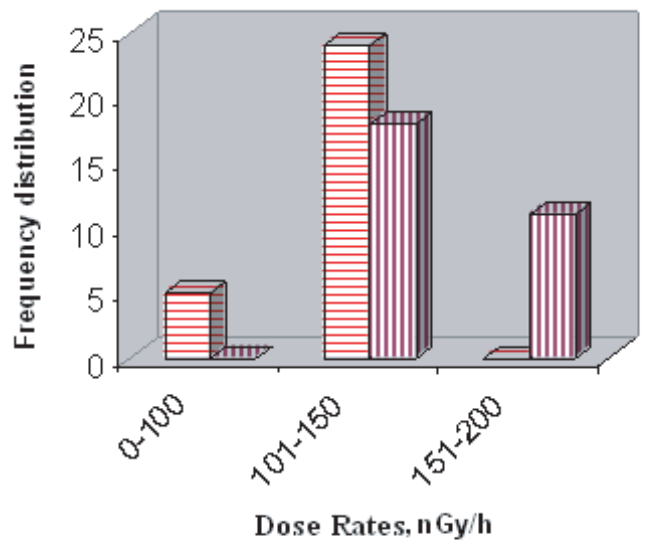

Figure 4 - Indoor, Outdoor gamma dose rates in Kotli area, Azad Jammu and Kashmir, Pakistan.

dose for the Kotli area is $0.64 \mathrm{mSv} \cdot \mathrm{y}^{-1}$ and $0.11 \mathrm{mSv} \cdot \mathrm{y}^{-1}$ for indoor and outdoor environs, respectively, with an average indoor to outdoor ratio of 5.8. The combined (indoor and outdoor) average ambient annual effective gamma dose is $0.37 \mathrm{mSv} . \mathrm{y}^{-1}$. This is consistent with the $(0.3$ to 0.6$) \mathrm{mSv}^{-1} \mathrm{y}^{-1}$ range for various countries of the world given by UNSCEAR, 2000. The relatively higher gamma dose rates obtained in this work recommend further detailed investigations on the concentration of gamma-emitting radionuclides in soil underneath the dwellings, in building materials and in substrate rock units of Kotli.

\subsection{Correlation between gamma dose and indoor radon concentration}

The relationship between indoor radon and gamma dose rates was examined in the present study. The linear correlation fit was applied for the indoor radon concentration and gamma dose rates and the correlation coefficient of that relation was found to be $23 \%$, showing a weak positive correlation between indoor radon and indoor gamma dose rates. There is an indication that the exhalation process which controls the indoor radon concentration may be influenced by factors such as ventilation rates, soil permeability and pressure differences, which may not be directly related to gamma radiation emitted indoors from building material and underlying soil.

This is similar to the weak positive correlation suggested between indoor radon concentrations and gamma dose rates in the literature (Fujimoto, 1998; Pilkyte et al., 2005; Makelain et al., 2001). 


\section{Conclusions}

Radon concentration during the summer was surveyed in the Kotli area, Azad Kashmir, using Kodak CN-85 Solid-State Nuclear Track Detectors. The mean radon concentration in Kotli dwellings observed in this preliminary study is on the higher side when compared with the average world value of $40 \mathrm{~Bq} \cdot \mathrm{m}^{-3}$ given by UNSCEAR, 2000. The radon concentration was observed to be higher in homes constructed with mud as compared with Pucka (cemented) dwellings. The mean radon potential in lithologies, i.e. the Murree and Nagri Formations, is reflected in higher than average values of radon concentration. The indoor radon concentration had a weak positive correlation with the dose rate in air due to gamma radiation. The findings reveal that the dwellings in the Kotli area in general are characterized by low radon exposure, and consequently it implies that the occupants of these dwellings are relatively safe from radon-induced health hazards. However, at some specific locations where radon concentrations were found to be higher than the US EPA action limit of $148 \mathrm{~Bq} . \mathrm{m}^{-3}$, proper action should be taken.

Acknowledgments. The authors wish to thank the University of Azad Jammu and Kashmir, Muzaffarabad, and the PINSTECH, Islamabad, for providing the necessary laboratory and research facilities to carry out this work. The authors are also thankful to the residents of selected dwellings in the study area for their cooperation during the installation and collection of the dosimeters and field work.

\section{REFERENCES}

Akhtar S.S., Ahmad M., Hussain A. (2004) Geological map of the Gulpur area, Kotli and Mirpur Districts, AJK, GeolSurv, Pakistan Map series, 6-26.

Akram M., Khattak N.U., IqbalArshid., Qureshi A.A., Ullah K., Qureshi I.E. (2005) Measurement of Radon concentration in dwellings of Skardu city, Pakistan, Rad. Meas. 40, 695-698.

Appleton J.D., Radon: Sources, Health Risks, and Hazard Mapping. (2007) J. Human Environment, 36(1), 85-89.

Baig M.S. (1991) Geochronology of pre-Himalayan and Himalayan tectonic events, Northwest Himalaya, Pakistan, Kashmir J. Geol. 8\&9, 197.

ChoubeyV.M., Ramola R.C. (1997) Correlation between geology and radon levels in groundwater,soil and ondoor air in Bhilangana valley, Garhwal Himalaya, India. Envir. geo. 32(4), 258-262.

Deka P.C., Sarkar S., Bhattacharjee B., Goswami T.D., Sharma B.K., Ramachandran T.V. (2003) Measurement of radon and thoron concentration by using LR-115 type-11 plastic track detectors in the environ of Brahamputra valley, Assam, India, Rad. Meas. 36, 431-434.

Erees F.S., Akozcan S., Parlak Y., Cam S., 2005. Assessment of dose rates around Manisa, Turkey, Rad. Meas. 41, 598-601.

Faheem M., Matiullah (2008) Indoor radon concentration levels in several districts of the Punjab province - Pakistan, Rad. Meas. 43, S380-S384. 
Fleischer R.L., Price P.B., Walker R.M. (1975) Nuclear Tracks in solids: Principles and Applications, University of California press, Berklay.

Fujimoto K. (1998) Correlation between indoor radon concentration and dose rate in air from terrestrial gamma radiation in Japan, Health Phys. 75,1-7.

Gillmore G.K., Jabarivasal N. (2010) A reconnaissance study of radon concentration in Hamadan city, Iran. Nat.Haz. Earth Sys. Sci. 10, 857-863.

ICRP (1993) International commission on Radiological Protection. Protection against radon at home and at work, ICRP Publication 65, Ann. ICRP 23 (2).

Iqbal A., Baig M.S., Akram M., Kazmi A., Saleem S., Qureshi A.A. (2008) Radon levels in dwellings of Mirpur Azad Kashmir, Sub Himalayas Pakistan: IndoorBuilt Environ. 17(5), 397-402.

Iqbal A., Baig M.S., Akram M., Abbasi S.A.(2010) Indoor radon concentration, outdoor gamma dose rates and impact of geology in the Dhirkot areas, Azad Jammu and Kashmir, sub-Himalayas, Pakistan, Radioprotection 45, 523-535.

Kam E., Bozkurt A. (2007) Environmental radioactivity measurements in Kastamonu region of northern Turky, Appl. Rad. Iso. 65, 440-444.

Karpinska M., WolkowiezS., Mnich Z., Zalewski M., Mamont-Ciesla K., Kapala J. (2002) Comparative studies of health hazard from radon (Rn-222) in two selected lithologic formations in the Suwalki region (Poland): J. Environ. Radioact. 61, 149-158.

Khan M.S., Naqvi A.H., Azam A. (2008) Study of indoor radon and its progeny levels in rural areas of north India using LR-115 plastic track detectors, Radiat. Meas. 43, S385-S388.

Khan S.A., Ali S., Tufail M., Qureshi A.A. (2005) Radon concentration levels in Fatima Jinnah Women University Pakistan, Radioprotection 40(1), 11-27.

Makelainen I., Arvela H., Voutilainen A. (2001) Correlations between radon concentration and indoor gamma dose rate, soil permeability and dwelling substructure and ventilation, Sci. Total Environ., 272, 283-289.

Moughal M.N., Khan R.U., Hussain A. (2004) Geological map of Kotli and Sudhnoti Districts AJK, Geol. Surv. Pakistan, Geological mapseries. 6-23.

Pilkyte L., Butkus D. (2005) Influence of gamma radiation of indoor radon decay products on absorbed dose rates, J. Environ. Engineer Landscape management 13-2, 65-72.

Rahman S.U., Anwar J., Matiullah. (2008) Measurement of indoor radon concentration levels in Islamabad, Pakistan, Rad. Meas. 43, S401-S404.

Ramola R.C., Negi M.S., ChoubeyV.M. (2005) Radon and thoron monitoring in the environment of Kumaun Himalayas:Survey and outcomes, J. Environ. Radioact. 9, 85-92.

Reddy B.S., Reddy M.S., Reddy C.G., Reddy P.Y., Reddy K.R. (2003) Airborne radioactivity levels in dwellings of Khammam district, Andhra Pradesh, India. Rad. Meas. 36, 503-506.

Singh S., Kumar A., Singh B. (2005a) Passive integrating radon studies for environmental monitoring in Hamirpur district, Himachal Pradesh, India using solid state nuclear trackdectectors, Radiat. Meas. 39, 81-85.

Singh S., Mehra R., Singh K. (2005b). Seasonal variation of indoor radon in dwellings of Malwa region, Punjab, Atmos. Environ. 39, 7761-7767.

Singh S., Sharma D.K., Kumar A. (2004) Environmental radon studies using solid state nuclear track detectors, J. Environ. Radioact. 76, 369-376

Sundal A.V., Henriksen H., Soldal O., Strand T. (2004) The influence of geological factors on indoor radon concentrations in Norway, Sci. Total Environ. 328, 41-53.

Tufail M., Ahmad N. (1992) Measurement of radon in some cities of Pakistan and assessment of Excess lung cancer risk, Nucl. Sci. J. 29(4), 263-272.

UNSCEAR (2000) United Nation Scientific Committee on the Effects of Atomic radiation, Report to the General Assembly, United Nations, New York. 
A. IQBAL et al.

US Environmental Protection Agency(EPA) 402/K-09/001A Citizen guide to Radon: The guide to protecting yourself and your family from Radon.

Yarar Y., Kam E. (2005) Environmental radioactivity concentrations of Tekirdag, Int. cong. series. 1276, 387-389.

Wadia D.N. (1928) The geology of Poonch state of (Kashmir) and adjacent areas of the Punjab: MemGeolSurv; Indian Records, 11.

Wadia D.N. (1931)). The syntaxis of the Northwest Himalaya: its rocks, tectonics and orogeny: Mem. Geol. Surv, Indian Records. 65, 185-370.

World Health Organisation (WHO) (2009). A hand book on indoor radon: A public health prospective. 